\title{
Identifying epidemiological factors affecting sea lice Lepeophtheirus salmonis abundance on Scottish salmon farms using general linear models
}

\author{
C. W. Revie ${ }^{1, *}$, G. Gettinby ${ }^{2}$, J. W. Treasurer ${ }^{3}$, C. Wallace $^{4}$ \\ ${ }^{1}$ Department of Computer and Information Sciences, and ${ }^{2}$ Department of Statistics and Modelling Science, University of \\ Strathclyde, Glasgow G1 1XH, UK \\ ${ }^{3}$ Sea Fish Industry Authority, Marine Farming Unit, Ardtoe, Acharacle, Argyll PH36 4LD, UK \\ ${ }^{4}$ Marine Harvest (Scotland) Ltd., Blar Mhor Industrial Estate, Fort William, Inverness-shire PH33 7PT, UK
}

\begin{abstract}
The variation in Lepeophtheirus salmonis sea lice numbers across 40 Scottish salmon farm sites during 1996 to 2000 was analysed using mean mobile abundance for 3 important 6 mo periods within the production cycle. Using statistical regression techniques, over 20 management and environmental variables suspected to have an effect on controlling lice populations were investigated as potential risk factors. The findings and models developed provide a picture of mobile L. salmonis infestation patterns on Scottish farm sites collectively. The results identified level of treatment, type of treatment, cage volume, current speed, loch flushing time and sea lice levels in the preceding 6 mo period to be key explanatory factors. Factors such as stocking density, site biomass, water temperature and the presence of neighbours, previously cited to be important correlates of sea lice risk from analysis of individual sites over time, were not found to be important. Variation in mobile abundance in the first half of the second year of production could be adequately explained (adjusted $\mathrm{R}^{2}$ between 55 and $72 \%$ ) by the recorded data, suggesting that there is scope for management to control L. salmonis abundance, though much of the variation remains unexplained.
\end{abstract}

KEY WORDS: Lepeophtheirus salmonis · Epidemiology · Linear modelling $\cdot$ Atlantic salmon $\cdot$ Fish farming $\cdot$ Expert panel

\section{INTRODUCTION}

Since the inception of salmon farming in the 1970s, sea lice infections have constantly remained an important disease affecting the health of both farmed and wild fish stocks. High burdens have presented a challenge to the viability of the salmonid aquaculture industry in Atlantic waters (Rae 2002). In Scotland the importance of controlling sea lice on farmed stocks has long been acknowledged and more recently reaffirmed in a governmental inquiry into aquaculture (Transport and the Environment Committee [TEC] 2002) which recommended that priority be given to understanding the epidemiology of sea lice burdens in farmed fish.
In recent years, a range of veterinary medicines has become available for the improved control of sea lice on farms, and these have been widely adopted by the industry together with a variety of management strategies and practices to reduce burdens to a minimum (Grant 2002). Such activities have been carefully regulated to ensure that administered treatments remain environmentally safe.

Despite progress, the epidemiology of sea lice infections remains poorly understood in the field (Pike \& Wadsworth 1999). The present study examined a wide range of epidemiological factors to see if any correlate with observed abundance (Bush et al. 1997) of the important mobile stages of Lepeophtheirus salmonis, the most prevalent sea lice species 
commonly found on Atlantic salmon Salmo salar L. stocks in Scotland.

The basis of the findings comes from an in-depth analysis of recorded sea lice counts over a 5 yr period from commercial farms across Scotland, and was made available by an industrial partner (Revie et al. 2002b). A 2-stage approach was adopted. In the first stage, potential risk factors were identified through consultation with industry health managers. In the second stage, data associated with these factors were analysed using rigorous statistical multiple regression methods to identify factors that could explain the variation in observed sea lice counts. Such statistical approaches are widely used in epidemiology, and have been recently adopted in an epidemiological study of cataracts in farmed salmon (Ersdal et al. 2001). The only other published report attempting to relate such a broad set of factors to sea lice abundances is that by Heuch \& Mo (2001), focusing on Norwegian salmon farms. Wallace (1998) addressed issues of hydrography, temperature and wind profile, but the study was limited to a 2 yr period at a single site.

Our findings show that the epidemiology of Lepeophtheirus salmonis mobile counts on Atlantic salmon may be influenced by a small number of both management and environmental factors at certain times during the production cycle. However, there is little evidence to support claims that a variety of other cited factors are important in limiting burdens.

\section{MATERIALS AND METHODS}

Study base. The study base was drawn from several sources. Records of Lepeophtheirus salmonis counts were available from the SULLepsiS (Strathclyde University LINK Leps in Salmon) health records database. This was established in 2001 following collaborative research work between the Universities of Strathclyde and Glasgow, the industrial partner Marine Harvest, and Scottish Quality Salmon. It consists of detailed counts on up to 5 stages of 2 sea lice species recorded from an examination of over 88000 randomly sampled fish (Treasurer \& Pope 2000) from around 40 commercial fish farms on the west coast of Scotland from 1996 to 2000. Further details of the SULLepsiS database are described in Revie et al. (2002c). Weekly counts of L. salmonis mobiles were organised according to site and year, to produce 120 site-years of weekly sea lice records, of which 63 site-years were based on fish in the first year of production and 57 on fish in the second year of production. For each site-year, times and types of treatment used to control infestations were also made available.

Environmental data sets spanning the years 1996 to 2000 provided a source of site records on water tem- perature and hydrographic features such as current speed, direction and loch flushing times for each of the site-years. A number of these parameters were routinely recorded at each site using continuous-recording meteorological devices, from which weekly and monthly summary statistics could be determined. Similarly, a data set associated with production was available which included such factors as time of stocking, cage size and weight of fish. Finally, visits to each farm were used to compile a data set including details such as the specific configuration of cages in a given siteyear, or whether neighbouring farms were members of an operational area management agreement.

The environmental, production and farm site data sets were combined with the health records database (containing the sea lice counts and treatment details) to provide data which were investigated to ascertain whether any of the recorded epidemiological factors correlated with changes in Lepeophtheirus salmonis abundance observed in different site-years.

Expert review panel for cause and effect analysis. In order to obtain a manageable set of possible factors affecting sea lice levels, a cause and effect analysis was undertaken (Owen 1989). An expert review panel of 7 health managers, based on experience of managing sea lice control at sites throughout Scotland, was set up. Each panel member drew up 2 lists of (up to 10) factors they considered to have a substantive effect on sea lice abundance. A Taguchi approach of classifying factors into control and noise parameters was applied (Gardiner \& Gettinby 1998). List 1 consisted of factors considered to be within the control of the farm management system. List 2 comprised factors outside this control. This enabled the panel to focus on both management and environmental factors. Factors on each list were ranked in order of importance, and all lists were then compared. Following discussion of the allotted ranks, a consensus was reached on the number and format of factors to be subjected to more rigorous quantitative analyses. Final inclusion of factors in the analysis was subject to the availability of information from health, management and environment records at each salmon farm.

Linear modelling. Linear models (Tabachnick \& Fidell 1996) are increasingly used in quantitative epidemiological studies to formulate and test hypotheses, and to construct statistical models that can explain outcomes related to disease in terms of independent variables. In the present study, the goal was to examine a range of management and environmental factors to identify whether any individual or combination of factors had a substantive effect on the recorded levels of sea lice.

Analyses have previously been applied to the mobile stage, as it causes the severest pathology to fish stocks, 
and the ovigerous female stage has been the target of sea lice control programmes (Rae 1999). Previous descriptive epidemiological studies (Bron et al. 1993, Wadsworth 1998, Revie et al. 2002a) have indicated considerable differences in mobile counts of Lepeophtheirus salmonis according to period within the production cycle on Scottish farms. In the present study, 3 mobile cohorts were examined: the average weekly $L$. salmonis mobile abundance during the second half of the first year of production (referred to as LepsMob_1.2) and the average weekly mobile abundance during the first and second halves of the second year of production (referred to as LepsMob_2.1 and LepsMob_2.2, respectively); and mobile abundance during the first 6 mo of the first production year, when $L$. salmonis levels are typically negligible.

For the purpose of the analysis, linear modelling methods to manage quality in production systems were adopted (Fowlkes \& Creveling 1995). In particular, an experimental design approach was used, whereby each factor was individually screened for evidence of effects on sea lice abundance. If the factor was recorded as binary data, e.g. a site which had 'bad' neighbours absent or present, it was left unchanged. If the factor was recorded at 3 or more discrete levels, such as number of treatments used at a site, or as continuous measurements, such as current speed at cage sites, then a ternary division was made. Data were ranked and, using an upper and lower limit, divided into 3 equal parts, where values above the upper limit were classified as high and those below the lower limit as low. For such factors, only data with high and low classifications were used in the univariate screening, on the basis that if no difference in sea lice abundance is detectable between the low and high levels, a factor effect was probably not present. Thereafter, for each factor, the 2 levels were compared for significant differences between means using a $t$-test and the linear model:

$$
Y_{i j}=\mu_{i}+\varepsilon_{i j}
$$

where $Y_{i j}$ denotes sea lice abundance at Site $i$ with factor level $j$ (low or high), $\mu_{i}$ the mean of sites with factor level $j$ (low or high), and $\varepsilon_{i j}$ the experimental error. An examination of sea lice counts distribution indicated that distributions were typically over-dispersed, and from the Box-Cox procedure the logarithmic transformation (ln) was the most appropriate. Consequently, in practice, $Y_{i j}$ took the values of $\ln$ (mean mobile abundance+1) avoiding the need to adjust for outliers, which occasionally occurred in the untransformed data. Results are presented showing the means for each level of each factor, the $95 \%$ confidence interval for the difference in means of the untransformed data, and the $\mathrm{p}$-value level of significance from applying the test to the log-transformed data. p-values of less than 0.05 were indicative of changes in the factor affecting sea lice abundance, however for the purpose of further multivariable analyses, all variables with $\mathrm{p}$-values less than 0.20 were retained as covariates and potential explanatory factors of sea lice variation. Analyses were undertaken using the proprietary statistics package Minitab (Version 13.1).

The general linear modelling approach was extended to multiple regression (Tabachnick \& Fidell 1996). Those factors $X_{. j}$ identified as significant at the $20 \%$ level in the univariate analysis were considered for inclusion in the general linear model:

$$
Y_{i j}=\alpha+\beta_{1} X_{i 1}+\beta_{2} X_{i 2}+\beta_{3} X_{i 3}+\ldots+\varepsilon_{i j}
$$

to estimate the population regression model, which accounted for most of the variation in the data. The forward selection procedure was adopted whereby the first most significant variable was selected for entry to the model. Thereafter forward entry on unselected variables and backward elimination on selected variables ( $p$-value greater than 0.15 ) was performed in turn until there was no significant improvement to the variation explained by the factors in the model. In these analyses all valid data records were used irrespective of whether the factor values had been classified low or high. Results illustrate both the predictive model and the amount of variation explained by the model.

In addition the standard regression model was fitted:

$\frac{Y_{i j}-\bar{Y}}{s_{Y}}=b_{1}^{\prime} \frac{X_{i 1}-\bar{X}_{1}}{s_{1}}+b_{2}^{\prime} \frac{X_{i 2}-\bar{X}_{2}}{s_{2}}+b_{3}^{\prime} \frac{X_{i 3}-\bar{X}_{3}}{S_{3}}+\ldots+e_{i j}$

where each of the variables has been standardised by subtracting its mean and dividing by the standard deviation. The standardised regression coefficients $b_{j}^{\prime}$ are dimensionless and give a measure of the relative importance of one $X$ variable to another in explaining $Y$.

\section{RESULTS}

\section{Identification of factors}

Key management and environmental factors were generated for consideration in the analysis. The consensus of the expert review panel regarding factors within farm management control is shown in Table 1a, where 12 factors are ranked in order of importance from population structure at time of treatment to stock type. The table provides a description of each factor and a brief justification as to why the factor was thought to be important. Many factors are supported by published findings as indicated, and others were based on the experience of health managers who mon- 
Table 1a. Factors within farm management control, in order of importance, affecting sea lice levels

\begin{tabular}{|c|c|c|}
\hline Factor & Description & Justification \\
\hline $\begin{array}{l}\text { Population structure } \\
\text { at treatment }\end{array}$ & $\begin{array}{l}\text { Relative abundance of key stages in the life } \\
\text { cycle of the lice population at time of treat- } \\
\text { ment }\end{array}$ & $\begin{array}{l}\text { Treatments vary in their effectiveness against differ- } \\
\text { ent lice stages (Wootten et al. 1982) so treating lice at } \\
\text { the appropriate time could be an important factor in } \\
\text { controlling overall levels (Roth et al. 1993) }\end{array}$ \\
\hline Neighbours & $\begin{array}{l}\text { Presence or absence of 'bad neighbour' farms } \\
\text { within a } 5 \mathrm{~km} \text { radius, with whom there is } \\
\text { no working Area Management Agreement } \\
\text { (AMA) }\end{array}$ & $\begin{array}{l}\text { Lice can move from one site to another in the imme- } \\
\text { diate locality. A key goal of an AMA is to ensure that } \\
\text { fallowing, stocking and lice treatment practices on } \\
\text { farms within a common loch are in synchrony (Rae } \\
\text { 1999) }\end{array}$ \\
\hline Treatment level & $\begin{array}{l}\text { Number of treatments used on a farm within } \\
\text { a given period }\end{array}$ & $\begin{array}{l}\text { Number of treatments administered on any farm will } \\
\text { be influenced by the levels of lice seen at that site } \\
\text { and will in turn affect subsequent levels of infestation } \\
\text { on the fish (Revie et al. 2002c). }\end{array}$ \\
\hline Treatment type & $\begin{array}{l}\text { Type of treatment intervention being used on } \\
\text { a site in the time period under consideration }\end{array}$ & $\begin{array}{l}\text { Certain treatments are known to be more effective } \\
\text { than others, so type of treatment will be an important } \\
\text { factor for determining mean lice abundance (Grant } \\
\text { 2002) }\end{array}$ \\
\hline Grading frequency & $\begin{array}{l}\text { Number of times that fish within a site are } \\
\text { subjected to a grading event }\end{array}$ & $\begin{array}{l}\text { Grading dislodges lice, so fish subject to frequent } \\
\text { grading events may have lower levels of infestation }\end{array}$ \\
\hline Strategic treatment & $\begin{array}{l}\text { Those sites taking part, since } 1996 \text { in the SQS } \\
\text { strategic intervention to treat fish at a com- } \\
\text { mon time in the second year of production } \\
\text { (Weeks } 10,17 \text { and } 24 \text { ) for all farms within a } \\
\text { common loch system }\end{array}$ & $\begin{array}{l}\text { Reducing sea lice levels simultaneously in a common } \\
\text { loch system should prevent migration and rapid } \\
\text { recovery, so farms taking part in this approach } \\
\text { should exhibit lower levels of sea lice infestation } \\
\text { (Wadsworth 1998, Rae 1999) }\end{array}$ \\
\hline Stocking density & $\begin{array}{l}\text { Average stocking density of fish in pens on a } \\
\text { site }\left(\mathrm{kg} \mathrm{m}^{-3}\right) \text { in the period under considera- } \\
\text { tion }\end{array}$ & $\begin{array}{l}\text { Reducing salmon stocking density on farms can lead } \\
\text { to lower lice loads (TEC 2002) }\end{array}$ \\
\hline Historical farm size & $\begin{array}{l}\text { Number of fish managed at the site over the } \\
\text { last } 2 \text { production cycles }\end{array}$ & $\begin{array}{l}\text { Having large numbers of fish in a particular location, } \\
\text { year on year, may influence the likelihood of low or } \\
\text { high infestations }\end{array}$ \\
\hline Net height & $\begin{array}{l}\text { Mean height of the pen nets used to hold fish } \\
\text { on a given site }\end{array}$ & $\begin{array}{l}\text { As infection of salmon tends to occur close to the } \\
\text { water surface, deeper nets may reduce contact } \\
\text { between host and parasite, and thus, abundance lev- } \\
\text { els (Heuch et al. 1995) }\end{array}$ \\
\hline Fallowing & $\begin{array}{l}\text { Number of weeks a site is left fallow between } \\
\text { one production cycle and the next }\end{array}$ & $\begin{array}{l}\text { In Scotland the practice of separating year classes of } \\
\text { fish and having a period of fallowing between each } \\
\text { production cycle has been widely adopted. Extend- } \\
\text { ing the period of fallowing could have a beneficial } \\
\text { effect (Bron et al. 1993, Grant \& Treasurer 1993) }\end{array}$ \\
\hline Automated feeding & $\begin{array}{l}\text { Presence of an automated feeding system } \\
\text { (with feedback) on a site during the period } \\
\text { under consideration }\end{array}$ & $\begin{array}{l}\text { More effective feeding and satiation of fish may } \\
\text { reduce contact between host and parasite at the sur- } \\
\text { face of the pens (Fernö et al. 1995, Lyndon \& Toovey } \\
\text { 2000) }\end{array}$ \\
\hline Stock type & $\begin{array}{l}\text { Proportion of stock on a farm which were } \\
\text { high grilse, etc. }\end{array}$ & $\begin{array}{l}\text { Different stock types may be more or less susceptible } \\
\text { to infestation by sea lice (MacKinnon 1998) }\end{array}$ \\
\hline
\end{tabular}

itor sea lice infections and maintain unpublished data sets.

It was necessary to adapt the list given in Table 1a in light of the available data, and of the 12 factors, 4 were removed. Historical data on grading frequency and installation dates for automated feeding systems were incomplete, while stock type was found to vary from pen to pen within a given site, such that no single stock type could be associated with a particular site-year. Although lice population structure was ranked as most important, there was no simple interpretation or agreement on how such a factor could be quantified. Conse- 
Table 1b. Factors outside farm management control, in order of importance, affecting sea lice levels

\begin{tabular}{|c|c|c|}
\hline Factor & Description & Justification \\
\hline Current pattern & $\begin{array}{l}\text { Pattern of current flows around a site may be } \\
\text { linear, oscillatory, etc. }\end{array}$ & $\begin{array}{l}\text { Given that lice may be carried to and from a site, the } \\
\text { hydrographic pattern may have an effect on overall } \\
\text { lice abundance levels (Løland 1993, Wallace 1998) }\end{array}$ \\
\hline Current speed & $\begin{array}{l}\text { Mean speed of water flowing though a par- } \\
\text { ticular site }\end{array}$ & $\begin{array}{l}\text { Current speed may inhibit or enhance lice attach- } \\
\text { ment and infestation (Boxshall 1976, Brenton-Davie } \\
\text { \& Kreiberg 1999, Mustafa et al. 2001) }\end{array}$ \\
\hline Temperature & $\begin{array}{l}\text { Seawater temperature in the period under } \\
\text { consideration }\end{array}$ & $\begin{array}{l}\text { Sea lice develop faster when temperatures are high, } \\
\text { so sites with high mean seawater temperatures could } \\
\text { experience higher levels of lice infestation (Boxaspen } \\
\text { 1997) }\end{array}$ \\
\hline Flushing time & $\begin{array}{l}\text { An estimate of the time (in d) it takes for the } \\
\text { contents of a loch to be exchanged as } \\
\text { described by Edwards \& Sharples (1986) }\end{array}$ & $\begin{array}{l}\text { Broad loch-level hydrographic characteristics can } \\
\text { have an effect on lice recruitment and retention at a } \\
\text { site (Costelloe et al. 1995) }\end{array}$ \\
\hline $\begin{array}{l}\text { Freshwater run-off/ } \\
\text { salinity }\end{array}$ & $\begin{array}{l}\text { Salinity of the seawater in the proximity of } \\
\text { the pens which varies between sites, and } \\
\text { which will be influenced by freshwater run- } \\
\text { off }\end{array}$ & $\begin{array}{l}\text { Sea lice have a preference for saline environments } \\
\text { and fish in freshwater lose lice burdens. Different } \\
\text { levels of salinity seen across sites might be expected } \\
\text { to affect the numbers of lice present (Heuch 1995) }\end{array}$ \\
\hline Wild fish & $\begin{array}{l}\text { Number of wild salmon running in a loch and } \\
\text { the proximity of such runs to salmon farm } \\
\text { sites }\end{array}$ & $\begin{array}{l}\text { Sites are fallowed before each production cycle and } \\
\text { fish are free of parasites. Presence and abundance of } \\
\text { wild fish can impact on lice infestation patterns and } \\
\text { levels (Tully et al. 1999, Butler 2002) }\end{array}$ \\
\hline Disease challenge & $\begin{array}{l}\text { Estimate of the site prevalence of any con- } \\
\text { comitant diseases, including such candidates } \\
\text { as IPN, ISA, BKD, etc. }\end{array}$ & $\begin{array}{l}\text { Diseased fish may be more susceptible to lice infesta- } \\
\text { tion (Wootten et al. 1982) }\end{array}$ \\
\hline Ambient light level & $\begin{array}{l}\text { Number of daylight hours that a farm experi- } \\
\text { ences at certain times in the production cycle }\end{array}$ & $\begin{array}{l}\text { Given that sea lice appear to be photo-tactic alter- } \\
\text { ation in the ambient light conditions may result in } \\
\text { changes in lice abundance levels (Fernö et al. 1995) }\end{array}$ \\
\hline Wind & $\begin{array}{l}\text { Strength and direction of prevailing winds at } \\
\text { a site in particular periods of the year }\end{array}$ & $\begin{array}{l}\text { Lice levels on sites in Norway may be affected by } \\
\text { prevailing winds (Wallace 1998). As wind drives sur- } \\
\text { face current, where lice are known to be present, it } \\
\text { could have an effect on sea lice recruitment to spe- } \\
\text { cific sites }\end{array}$ \\
\hline
\end{tabular}

quently, no consideration could be given to this factor. Following consideration of farm size, it was decided to split this variable into 2 related factors: (1) to reflect the historical situation, i.e. whether the site had low or high numbers of fish in previous years, and (2) to represent mean biomass level on the site during the period in question. Finally, because the net height of cages varied little, cage volume was allocated as a surrogate measure. Thus, the final number of management factors agreed by the expert review panel for further analysis was 9.

The panel were also asked to rank factors they considered to be outside farm management control. These were principally environmental factors, associated with the spatial location of the farm, as can be seen from the list and descriptions given in Table $1 \mathrm{~b}$. A total of 9 factors were identified, of which current pattern and current speed were the 2 most highly ranked factors, while wind speed and direction had the lowest rank. Data sources relating to freshwater run-off (Edwards \& Sharples 1986) and wild fish runs were not available for the sites during the periods in question. Data on disease challenge, seawater salinity and wind speed were incomplete, and as previous analyses had indicated no regional variations (Revie et al. 2002a) it was decided not to pursue ambient light levels as a factor. This led to the omission of 5 factors originally identified by the panel as of interest, and left 4 factors which were also those ranked as most important. Temperature was divided into 3 related factors: (1) mean weekly temperature in the coldest period of the year (Quarter 1); (2) mean weekly temperature in the warmest period of the year (Quarter 3), and (3) difference between maximum and minimum temperatures representing the extremity of values occurring at a site. A total of 6 factors outside farm management control were therefore available for further investigation. 
Table 2. Classification of factors showing the cut-off levels used for ternary division of the data into low and high classes, as per analysis of Lepeophtheirus salmonis mobile abundance data at various stages in the production cycle. -: factors not applicable for a 6 mo period, na: not applicable

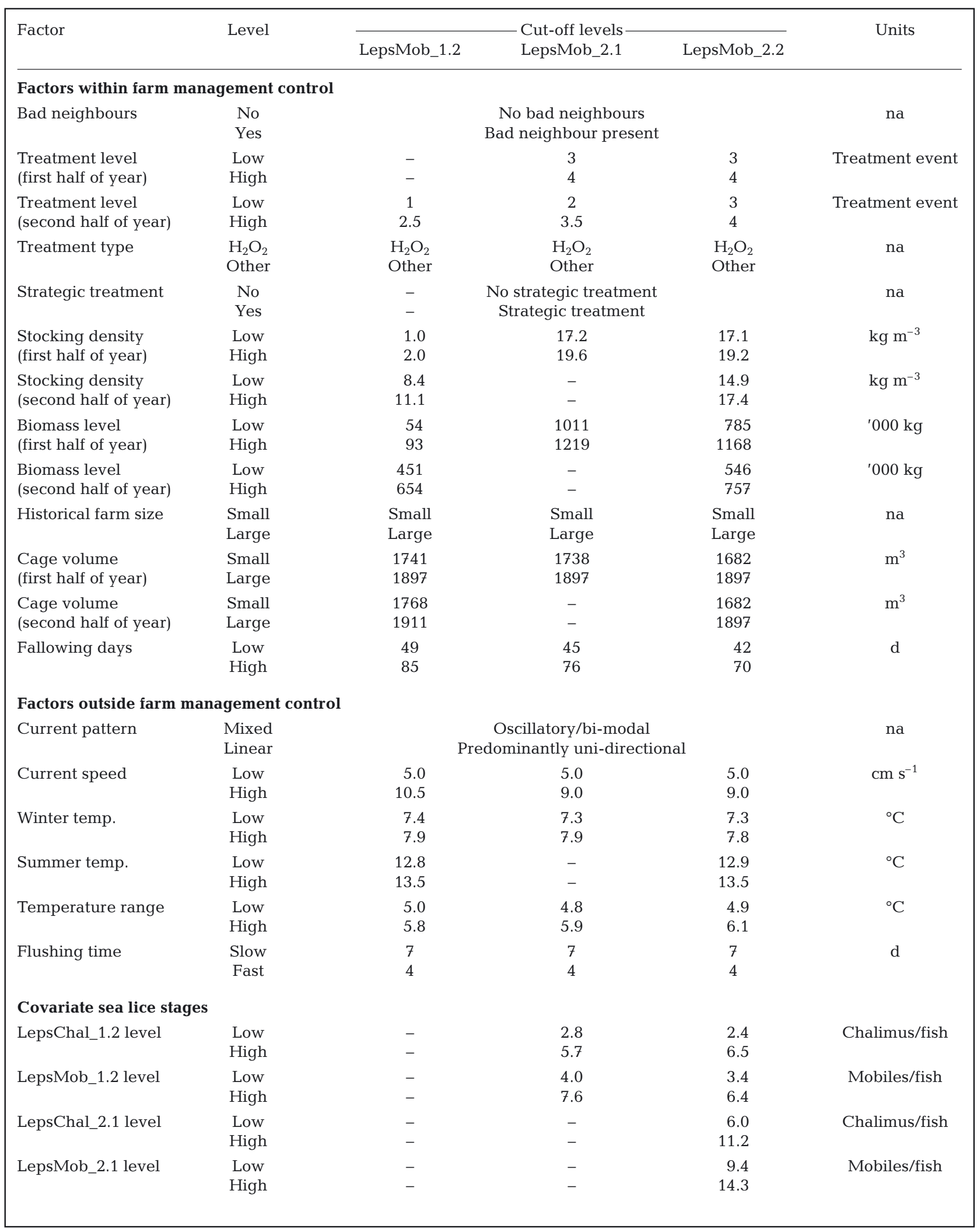


The final list of 15 factors used in the analysis is shown in Table 2. In addition, covariate factors defining lice levels in preceding periods are included. For each variable, the threshold values at which the factor was categorised into the upper and lower ternary divisions is listed. Where the factors were not based on continuous data, membership categories were chosen, as shown in the table. Following univariate tests on the mean Lepeophtheirus salmonis mobile abundance values associated with low and high levels of the factors, Table 3 shows those factors found to be significant $(p<0.20)$ and therefore included in the multiple regression analysis. Table 3 also shows the size of factor effect, which is the mean difference in the sea lice counts of the low and high levels of each factor, and the associated $95 \%$ confidence interval for the difference. Note that p-values are those associated with the log-transformed data used in the analysis, whereas the means and confidence intervals reported are for sea lice abundance. The final set of factors for regression analysis consisted of this subset of both management and environmental variables, and several covariate sea lice stage variables, as listed in Table 3.

Table 3. Mean Lepeophtheirus salmonis mobile abundance and confidence intervals (CI) for differences between levels for each of the factors entered into stepwise multiple regression $(p<0.20) .{ }^{*} p$-values obtained using transformed lice counts, - : factors not applicable for the indicated 6 mo period

\begin{tabular}{|c|c|c|c|c|c|c|c|c|c|c|}
\hline \multirow[t]{2}{*}{ Factor } & \multirow[t]{2}{*}{ Level } & \multicolumn{3}{|c|}{ — LepsMob_1.2 } & \multicolumn{3}{|c|}{ — LepsMob_2.1 } & \multicolumn{3}{|c|}{ —LepsMob_2.2 } \\
\hline & & Mean (n) & $\mathrm{CI}$ & $\mathrm{p}$ & Mean (n) & $\mathrm{CI}$ & $\mathrm{p}$ & Mean (n) & CI & $\mathrm{p}$ \\
\hline \multicolumn{11}{|c|}{ Factors within farm management control } \\
\hline $\begin{array}{l}\text { Treatment level } \\
\text { (first half of year) }\end{array}$ & $\begin{array}{l}\text { Low } \\
\text { High }\end{array}$ & - & - & - & $\begin{array}{c}9.6(22) \\
15.7(24)\end{array}$ & $(1.9,10.4)$ & 0.01 & & & \\
\hline $\begin{array}{l}\text { Treatment level } \\
\text { (second half of year) }\end{array}$ & $\begin{array}{l}\text { Low } \\
\text { High }\end{array}$ & $\begin{array}{l}1.7(13) \\
7.5(19)\end{array}$ & $(3.3,8.4)$ & 0.00 & - & - & - & $\begin{array}{l}22.1(12) \\
16.9(14)\end{array}$ & $(-11.9,1.4)$ & 0.12 \\
\hline $\begin{array}{l}\text { Treatment type } \\
\text { (first half of year) }\end{array}$ & $\begin{array}{l}\mathrm{H}_{2} \mathrm{O}_{2} \\
\text { Other }\end{array}$ & - & - & - & $\begin{array}{l}16.5(25) \\
10.2(22)\end{array}$ & $(-10.4,-2.2)$ & 0.00 & $\begin{array}{l}23.5(20) \\
15.2(14)\end{array}$ & $(-13.9,-2.8)$ & 0.01 \\
\hline $\begin{array}{l}\text { Treatment type } \\
\text { (second half of year) }\end{array}$ & $\begin{array}{l}\mathrm{H}_{2} \mathrm{O}_{2} \\
\text { Other }\end{array}$ & $\begin{array}{l}7.9(19) \\
4.7(29)\end{array}$ & $(-5.6,-0.9)$ & 0.00 & - & - & - & $\begin{array}{l}23.3(23) \\
15.0(14)\end{array}$ & $(-13.5,-3.3)$ & 0.00 \\
\hline $\begin{array}{l}\text { Stocking density } \\
\text { (second half of year) }\end{array}$ & $\begin{array}{l}\text { Low } \\
\text { High }\end{array}$ & $\begin{array}{l}3.9(21) \\
6.9(21)\end{array}$ & $(0.2,5.9)$ & $0.17^{*}$ & - & - & - & $\begin{array}{l}16.8(15) \\
21.8(15)\end{array}$ & $(-1.3,11.3)$ & 0.12 \\
\hline $\begin{array}{l}\text { Biomass level } \\
\text { (second half of year) }\end{array}$ & $\begin{array}{l}\text { Low } \\
\text { High }\end{array}$ & $\begin{array}{l}4.7(21) \\
6.3(21)\end{array}$ & $(-1.2,4.2)$ & 0.14 & - & - & - & & & \\
\hline Historical farm size & $\begin{array}{l}\text { Low } \\
\text { High }\end{array}$ & $\begin{array}{l}5.4(28) \\
5.9(20)\end{array}$ & $(-1.8,2.9)$ & 0.13 & & & & & & \\
\hline $\begin{array}{l}\text { Cage volume } \\
\text { (second half of year) }\end{array}$ & $\begin{array}{l}\text { Small } \\
\text { Large }\end{array}$ & $\begin{array}{l}5.3(21) \\
3.7(21)\end{array}$ & $(-4.4,1.0)$ & $0.04^{*}$ & - & - & - & & & \\
\hline \multicolumn{11}{|c|}{ Factors outside farm management control } \\
\hline Current pattern & $\begin{array}{l}\text { Mixed } \\
\text { Linear }\end{array}$ & & & & $\begin{array}{l}16.4(25) \\
11.0(25)\end{array}$ & $(-9.5,-1.1)$ & 0.01 & & & \\
\hline Current speed & $\begin{array}{l}\text { Low } \\
\text { High }\end{array}$ & & & & $\begin{array}{l}15.8(23) \\
11.4(24)\end{array}$ & $(-8.9,0.1)$ & $0.05^{*}$ & & & \\
\hline Winter temperature & $\begin{array}{l}\text { Low } \\
\text { High }\end{array}$ & & & & $\begin{array}{l}10.8(18) \\
15.5(18)\end{array}$ & $(-0.2,9.5)$ & 0.11 & & & \\
\hline Flushing time & $\begin{array}{l}\text { Slow } \\
\text { Fast }\end{array}$ & $\begin{array}{l}6.6(23) \\
4.8(34)\end{array}$ & $(-4.3,0.6)$ & 0.13 & $\begin{array}{l}17.2(24) \\
10.3(29)\end{array}$ & $(-10.9,-2.7)$ & 0.00 & & & \\
\hline \multicolumn{11}{|c|}{ Covariate sea lice stages } \\
\hline LepsChal_1.2 level & $\begin{array}{l}\text { Low } \\
\text { High }\end{array}$ & - & - & - & $\begin{array}{l}12.4(14) \\
16.4(14)\end{array}$ & $(-2.1,10.2)$ & 0.18 & & & \\
\hline LepsMob_1.2 level & $\begin{array}{l}\text { Low } \\
\text { High }\end{array}$ & - & - & - & $\begin{array}{l}11.3(14) \\
13.8(14)\end{array}$ & $(-2.0,7.0)$ & 0.18 & & & \\
\hline LepsChal_2.1 level & $\begin{array}{l}\text { Low } \\
\text { High }\end{array}$ & - & - & - & - & - & - & $\begin{array}{l}18.0(15) \\
21.6(15)\end{array}$ & $(-2.0,9.2)$ & 0.18 \\
\hline LepsMob_2.1 level & $\begin{array}{l}\text { Low } \\
\text { High }\end{array}$ & - & - & - & - & - & - & $\begin{array}{l}13.2(15) \\
26.0(15)\end{array}$ & $(7.7,17.9)$ & 0.00 \\
\hline
\end{tabular}




\section{Explaining sea lice counts using regression modelling}

Table 4 shows the results of regressing the log-transformed mean weekly mobile abundance for the second half of the first year of production on the factors listed in Table 3 and identified as significant for LepsMob_1.2. Only 2 factors, Treatment level and Cage volume, are identified as significant. The regression coefficient for level of treatment is positive, reflecting that the number of treatments increased as sea lice abundance increased. In contrast, as cage volume increases, the sea lice abundance declines.

The appropriateness of a linear model fit is illustrated in Fig. 1. Both the histogram of the residuals and

Table 4. Results of stepwise multiple regression of log-transformed mean weekly Lepeophtheirus salmonis mobile abundance in the 0 half of the first year of production, on management and environmental factors. Coeff: coefficient

Regression model

ln $($ LepsMob_1.2 + 1) $=2.055+0.266$ Treatment level -0.00048 Cage volume

\begin{tabular}{lccccc} 
Model term & Coeff & $\begin{array}{c}\text { Coeff } \\
\text { SD }\end{array}$ & $\begin{array}{c}\text { Standardised } \\
\text { Coeff } b_{j}^{\prime}\end{array}$ & p & $\begin{array}{c}\text { Adj. } R^{2} \\
(\%)\end{array}$ \\
\hline Constant & 2.055 & & & & \\
Treatment level & 0.266 & 0.0543 & 0.52 & 0.001 & 37.5 \\
Cage volume & -0.00048 & 0.00016 & -0.33 & 0.004 & 46.4 \\
\hline
\end{tabular}

Table 5. Results of stepwise multiple regression of (a) log-transformed mean weekly Lepeophtheirus salmonis mobile abundance in the first half of the second year of production on management and environmental factors, and (b) with covariate sea lice counts from preceding 6 mo period. Coeff: coefficient

(a) Regression model

$\ln ($ LepsMob_2.1 +1$)=1.97+0.211$ Treatment level -0.414 Treatment type 0.022 Current speed +0.055 Flushing time

\begin{tabular}{lccccr} 
Model term & Coeff & $\begin{array}{c}\text { Coeff } \\
\text { SE }\end{array}$ & $\begin{array}{c}\text { Standardised } \\
\text { Coeff } b_{j}{ }^{\prime}\end{array}$ & $\mathrm{p}$ & $\begin{array}{c}\text { Adj. } \mathrm{R}^{2} \\
(\%)\end{array}$ \\
\hline Constant & 1.97 & & & & \\
Treatment level & 0.211 & 0.062 & 0.40 & 0.002 & 28.9 \\
Treatment type & -0.414 & 0.12 & -0.40 & 0.002 & 48.3 \\
Current speed & -0.022 & 0.011 & -0.24 & 0.048 & 51.2 \\
Flushing time & 0.055 & 0.029 & 0.22 & 0.068 & 54.6
\end{tabular}

(b) Regression Model

ln $($ LepsMob_2.1 +1$)=1.96-0.58$ Treatment type +0.15 Treatment level + 0.042 LepsChal_1.2 + 0.058 Flushing time 0.014 Current speed

\begin{tabular}{lccccc} 
Model term & Coeff & $\begin{array}{c}\text { Coeff } \\
\text { SE }\end{array}$ & $\begin{array}{c}\text { Standardised } \\
\text { Coeff } b_{j}^{\prime}\end{array}$ & $\mathrm{p}$ & $\begin{array}{c}\text { Adj. } \mathrm{R}^{2} \\
(\%)\end{array}$ \\
\hline Constant & 1.96 & & & & \\
Treatment type & -0.58 & 0.11 & -0.54 & 0.000 & 39.2 \\
Treatment level & 0.15 & 0.053 & 0.30 & 0.009 & 58.9 \\
LepsChal_1.2 & 0.042 & 0.016 & 0.28 & 0.013 & 68.1 \\
Flushing time & 0.058 & 0.026 & 0.23 & 0.037 & 70.8 \\
Current speed & -0.014 & 0.0093 & -0.15 & 0.141 & 72.1 \\
& & & & & \\
\hline
\end{tabular}

the normal score plot suggest that a linear model structure can be used to describe the relationship between it was therefore concluded that abundance of mobile sea lice on salmon in the second half of the first year of production can only be partially explained, with the most important explanatory variables being level of nt and cage volume. Level of treatment, type of treatment, current speed lice abundance. As type of treatment changes, from hydrogen peroxide to either organophosphate or synthetic pyrethroid, and as current speed increases, sea lice abundance decreases. In contrast, as level of treatment or flushing time increases, sea lice abundance increases. This model accounted for $55 \%$ of the variation in mobile lice abundance, and the beta coefficients indicated that unit changes in both treatment level and treatment type had the greatest influence on sea lice abundance. When the model is extended to explore whether sea lice levels experienced in the preceding 6 mo period can further explain the variation in sea lice abundance, Table 5b shows that the amount of variation explained increases substantially from 55 to $72 \%$. It would therefore appear that chalimus levels in the second half of the first year do have a bearing on mobile abundance experienced in the first half of the second year of production.

Finally, for mobile lice abundance in the final 6 mo of the $2 \mathrm{yr}$ production cycle, Table 6 shows that type of treatment is the only control factor to significantly explain levels, with mobile levels from the previous 6 mo also registering as significant. When the linear model is restricted to the control factors, only $20 \%$ of the variation can be explained, while including previous levels of chalimus and mobiles as covariates increases this to just over $26 \%$. Therefore, mobile sea lice abundance for this period remains unpredictable. 

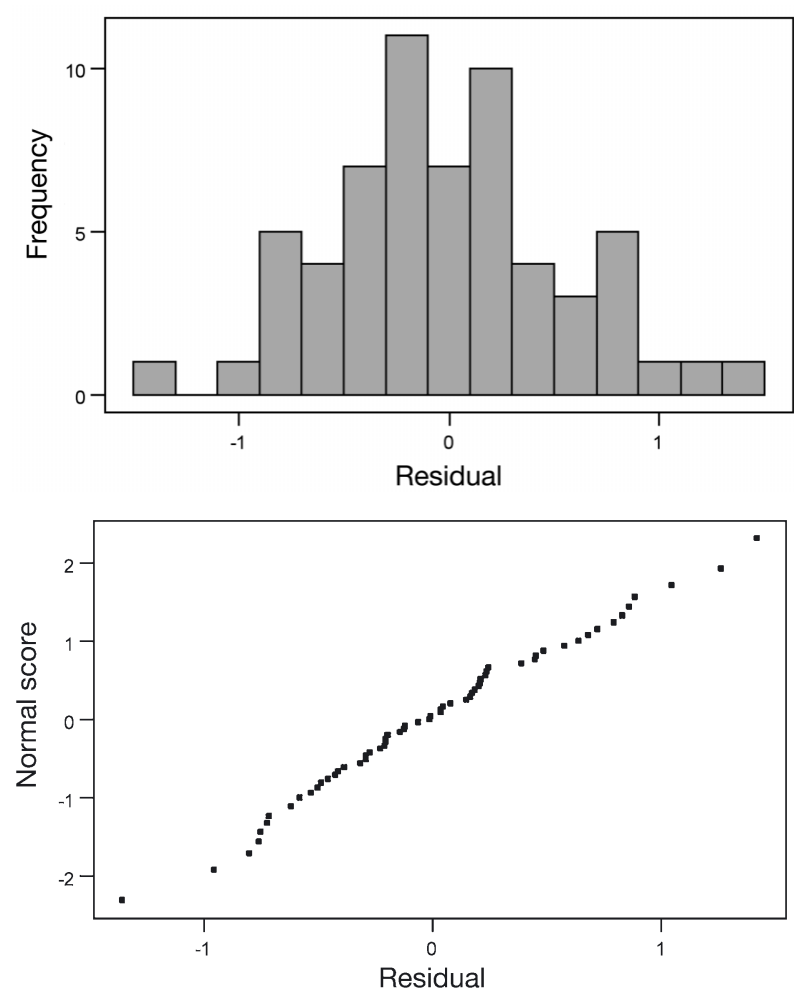

Fig. 1. Diagnostic residual plots for stepwise multiple regression model of ln (LepsMob_1.2 + 1) on management factors Treatment level and Cage volume

\section{DISCUSSION}

Several important conclusions can be drawn from statistical regression analysis of management and environmental factors. Treatment level, treatment type and cage volume were found to have an influence on mobile sea lice abundance from the 9 factors identified by the expert panel as being within management control. Stocking density, biomass, strategic treatment, bad neighbours and length of fallowing were found not to significantly explain any of the variation. Of the factors identified by the expert panel as being outside farm management control, and for which data existed, only current speed and flushing time were found to be significant. Water temperature and current pattern were found not to have any significant impact.

The extent to which variation in mobile abundance could be explained depended on the 6 mo period of the production cycle in question. Almost $50 \%$ of the variation in mobile sea lice abundance from July to December in the first year of production could be explained by treatment level and cage volume. For the following period, from January to June in the second year of production, almost $55 \%$ of the variation could be explained using treatment level, treatment type, current speed and flushing time. However, including chalimus levels for July to December of the preceding year increased the explanation of the variation from 55 to $72 \%$. This is by far the best explanation of all the sea lice abundances, and suggests that, at least for this period, mobile abundance may be manipulated by choosing the right combination of managed treatment and site location. This is particularly important, as this period has been identified as the critical time for maintaining low mobile lice abundance, as wild smolts may be running in nearby rivers (Butler 2002). However, when it comes to explaining Lepeophtheirus salmonis abundance in the last 6 mo of production, when mobiles are normally at their highest and present a significant threat to farm production and health, there is no satisfactory combination of factors. Type of treatment is the single most important driving factor, but this alone, or in combination with lice levels from the preceding period, is insufficient and can explain no more than $26 \%$ of the variation.

Differences from one 6 mo period to another are to be expected, as the stage of sea lice development and the treatment management response differs. In particular, it would appear that as treatment becomes important in the second half of the second year, with each treatment decimating the sea lice population, before recovery is seen several weeks later (Revie et al. 2002a), the undulations produced in the population levels far exceed any effect that other environmental or management factors exert.

Water temperature has been cited in several studies as an important determinant of sea lice abundance (Tully 1989, Johnson \& Albright 1991, Tully 1992, Boxaspen 1997, Tucker et al. 2000, Mustafa et al. 2001). However, at the level of site-year analysis across a range of sites in Scotland, it does not appear to be a significant explanatory factor. The involvement of

Table 6. Results of stepwise multiple regression of log-transformed mean weekly Lepeophtheirus salmonis mobile abundance in the second half of the second year of production, on management and environmental factors and covariate sea lice counts from the preceding 6 mo period. Coeff: coefficient

Regression model

ln $($ LepsMob_2.2 + 1) $=2.910-0.34$ Treatment type +0.0113 LepsMob_2.1

\begin{tabular}{lccccc} 
Model term & Coeff & $\begin{array}{c}\text { Coeff } \\
\mathrm{SD}\end{array}$ & $\begin{array}{c}\text { Standardised } \\
\text { Coeff } b_{j}^{\prime}\end{array}$ & $\mathrm{p}$ & $\begin{array}{c}\text { Adj. } \mathrm{R}^{2} \\
(\%)\end{array}$ \\
\hline Constant & 2.910 & & & & \\
Treatment type & -0.34 & 0.14 & -0.38 & 0.02 & 20.0 \\
LepsMob_2.1 & 0.0113 & 0.0058 & 0.31 & 0.06 & 26.1 \\
\hline
\end{tabular}


Scottish farms in a 'strategic' treatment framework has been encouraged over the past few years (Rae 1999), and around half the farms within the data set had adopted the proposed approach during the period under review. There was no evidence that adoption of the strategic treatment approach acted as a significant factor. It may be the case that the full strategic approach proposed by Scottish Quality Salmon could not be adequately pursued, particularly in the early years of the study when access to suitable medicines was limited. There has been discussion in the Scottish press over the importance of stocking density in determining sea lice levels, and this was reinforced in a recently released parliamentary committee report (TEC 2002). However, the analysis used in this study shows that no significant explanatory value can be derived from the inclusion of either stocking density or biomass levels within the model. Similarly it had been claimed that 'the use of longer fallow periods is more effective than the use of short fallows' (Bron et al. 1993). This claim was made on the basis of a small data set (2 Scottish sites with a 'long' fallow period against 1 with a 'short' period) and the analysis presented here suggests that no such association can be demonstrated.

One observation from the linear modelling is that the regression coefficient for level of treatment was positive, yet it might be expected that as treatment intensity increased, sea lice abundance would decrease. The anomaly of the positive correlation between sea lice abundance and level of treatment arises because treatments would appear to be in proportion to challenge, but are insufficient to consistently drive down the overall level of the lice population. A similar phenomenon was noted in an earlier study (Revie et al. 2002c) into the effects of veterinary medicines on sea lice abundance.

The directions of the relationship between remaining factors and the sea lice burden were as expected. The use of more recently licensed veterinary medicines, and an increase in current speed, both correlate with a decrease in lice abundance. Newer medicines are often more efficacious and initially devoid of problems relating to parasite resistance (Denholm et al. 2002, Grant 2002), while high current speeds may both wash larval lice from a site more quickly and also disrupt the attachment of copepodids to the fish (Mustafa et al. 2001). In contrast, flushing time and levels of lice in the preceding period are positively correlated. Those sites with long flushing times will benefit less from the dispersive effect of tidal flush, while high levels of chalimus or mobiles on fish in the preceding period can be expected to give rise to higher subsequent levels of mobiles.

Despite great care being taken in the compilation of this large database, and the quantitative rigour applied to the analysis, it is recognised that this study has shortcomings. It should be noted that some factors have not been included in the final regression model, as they are highly correlated with those factors included in the model. For example, current pattern, when considered independently, was found to be discriminatory for mobile levels in the first half of the second year, but did not feature in the final explanatory model. In addition, it proved impossible to make use of the population structure of sea lice at time of treatment, or a number of other factors identified by the expert panel as potentially important. Nevertheless, the findings of the present study provide insight into mechanisms driving mobile abundance of Lepeophtheirus salmonis on farmed salmon, and suggest that further improved control should focus on key management factors.

Acknowledgements. This study was funded by MAFF (Ministry of Agriculture, Fisheries and Food) under the LINK Aquaculture programme (ENV 12), Defra (Department for the Environment Food and Rural Affairs) Project VM02134 and by Scottish Quality Salmon. The industrial partner is Marine Harvest (Scotland) Ltd., and thanks are due to their support staff, and in particular to the company's regional health managers: Mrs. C. Cox, Mr. R. Hopewell, Mr. C. Johnston, Mr. A. MacLennan and Mr. A. Morrison.

\section{LITERATURE CITED}

Boxaspen K (1997) Geographical and temporal variation in abundance of salmon lice (Lepeophtheirus salmonis) on salmon (Salmo salar L.). ICES J Mar Sci 54:1144-1147

Boxshall GA (1976) The host specificity of Lepeophtheirus pectoralis (Müller, 1776) (Copepoda: Caligidae). J Fish Biol 8:225-24

Brenton-Davie V, Kreiberg H (1999) Observations on sealice in Atlantic salmon raised in a SEA System ${ }^{\mathrm{TM}}$ floating bag and a conventional netpen. Bull Aquacul Assoc Canada 99-4:22-24

Bron JE, Sommerville C, Wootten R, Rae GH (1993) Fallowing of marine Atlantic salmon, Salmo salar L., farms as a method for the control of sea lice, Lepeophtheirus salmonis (Krøyer, 1837). J Fish Dis 16:487-493

Bush AO, Lafferty KD, Lotz JM, Shostak AW (1997) Parasitology meets ecology on its own terms: Margolis et al. revisited. J Parasitol 83:575-583

Butler JRA (2002) Wild salmonids and sea louse infestations on the west coast of Scotland: sources of infection and implications for the management of marine salmon farms. Pest Man Sci 58:595-608

Costelloe J, Costelloe M, Roche N (1995) Variation in sea lice infestation on Atlantic salmon smolts in Killary Harbour, West Coast of Ireland. Aquac Int 3:379-393

Denholm I, Devine GJ, Horsberg TE, Sevatdal S, Fallang A, Nolan DV, Powell R (2002) Analysis and management of resistance to chemotherapeutants in salmon lice, Lepeophtheirus salmonis (Copepoda: Caligidae). Pest Manag Sci 58:528-536

Edwards A, Sharples F (1986) Scottish sea lochs: a catalogue. Scottish Marine Biological Association (now SAMS), for: 
Nature Conservancy Council, Peterborough Ersdal C, Midtlyng PJ, Jarp J (2001) An epidemiological study of cataracts in seawater farmed Atlantic salmon Salmo salar. Dis Aquat Org 45:229-236

Fernö A, Huse Juell JE, Bjordal Å (1995) Vertical distribution of Atlantic salmon (Salmo salar L.) in net pens: trade-off between surface light avoidance and food attraction. Aquaculture 132:285-296

Fowlkes WY, Creveling CM (1995) Engineering methods for robust product design: using Taguchi methods in technology and product development. Addison-Wesley, New York

Gardiner WP, Gettinby G (1998) Experimental design techniques in statistical practice. Ellis Horwood, Chichester

Grant AN (2002) Medicines for sea lice. Pest Manag Sci 58: 521-527

Grant AN, Treasurer JW (1993) The effects of fallowing on caligid infestations on farmed atlantic salmon (Salmo salar L.) in Scotland. In: Boxshall GA, Defaye D (eds) Pathogens of wild and farmed fish: sea lice. Ellis Horwood, Chichester, p 255-260

Heuch PA (1995) Experimental evidence for aggregation of sea louse copepodids (Lepeophtheirus salmonis) in steep salinity gradients. J Mar Biol Assoc UK 75:927-939

Heuch PA, Mo TA (2001) Sea louse infection patterns in Norwegian salmon farms: correlations with management and environmental factors. Poster presented at the SCI Conference Salmon farming: towards an integrated pest management strategy for sea lice, 18-19 June, 2001 in Aberdeen

Heuch PA, Parsons A, Boxaspen K (1995) Diel vertical migration: a possible host-finding mechanism in salmon louse (Lepeophtheirus salmonis) copepodids? Can J Fish Aquat Sci 52:681-689

Johnson SC, Albright LJ (1991) Development, growth, and survival of Lepeophtheirus salmonis (Copepoda: Caligidae) under laboratory conditions. J Mar Biol Assoc UK 71: 425-436

Løland G (1993) Current forces on and water flow through and around floating fish farms. Aquac Int 1:72-89

Lyndon AR, Toovey JPG (2000) Does the Aquasmart ${ }^{\text {TM }}$ feeding system reduce sea louse [Lepeophtheirus salmonis (Krøyer)] infestation on farmed Atlantic salmon (Salmo salar L.) in winter? Aquac Res 31:843-847

MacKinnon BM (1998) Host factors important in sea lice infections. ICES J Mar Sci 55:188-192

Mustafa A, Peters WD, Conboy GA, Burka JF (2001) Do water temperature and flow affect sea lice development and settlement? In: Hendry CI, McGladdery SE (eds) Proc 18th meeting of the Aquaculture Association of Canada, Halifax NS, May 6-9, 2001. Aquacul Assoc Canada Spec Publ, St Andrews, NB, p 60-63

Owen M (1989) SPC and continuous improvement. IFS Publications, Springer-Verlag, Berlin

Pike AW, Wadsworth SL (1999) Sealice on salmonids: their biology and control. Adv Parasitol 44:233-337

Rae GH (1999) Sea lice, medicines and a national strategy for control. Fish Vet J 3:46-51

Editorial responsibility: Carl Schreck,

Corvallis, Oregon, USA
Rae GH (2002) Sea louse control in Scotland, past and present. Pest Manag Sci 58:515-520

Revie CW, Gettinby G, Treasurer JW, Rae GH, Clark N (2002a) Temporal, environmental and management factors influencing the epidemiological patterns of sea lice (Lepeophtheirus salmonis) infestations on farmed Atlantic salmon (Salmo salar L.) in Scotland. Pest Manag Sci 58:576-584

Revie CW, Gettinby G, Treasurer JW, Rae GH (2002b) The epidemiology of the sea lice, Caligus elongatus Nordmann, in marine aquaculture of Atlantic salmon, Salmo salar L., in Scotland. J Fish Dis 23:309-320

Revie CW, Gettinby G, Treasurer JW, Grant AN, Reid SWJ (2002c) Sea lice infestation on Atlantic salmon and the use of ectoparasitic treatments on commercial farms in Scotland. Vet Rec December 21/28:753-757

Roth M, Richards RH, Sommerville C (1993) Current practices in the chemotherapeutic control of sea lice infestations in aquaculture: a review. J Fish Dis 16:1-26

Tabachnick BG, Fidell LS (1996) Using multivariate statistics. Harper Collins, New York

TEC (2002) Report on Phase 2 of the inquiry into aquaculture (11th Report 2002). (Available at: www.scottish.parliament.uk/official_report/cttee/trans-02/trr02-11-vol01-01. $\mathrm{htm})$

Treasurer JW, Pope JA (2000) Selection of host sample number and design of a monitoring programme for ectoparasitic sea lice (Copepoda: Caligidae) on farmed Atlantic Salmon. Aquaculture 187:247-260

Tucker CS, Sommerville C, Wootten R (2000) The effect of temperature and salinity on the settlement and survival of copepodids of Lepeophtheirus salmonis (Krøyer, 1837). J Fish Dis 23:309-320

Tully O (1989) The succession of generations and growth of the caligid copepods Caligus elongatus and Lepeophtheirus salmonis parasitising farmed Atlantic salmon smolts (Salmo salar L.). J Mar Biol Assoc UK 69:279-287

Tully O (1992) Predicting infestation parameters and impacts of caligid copepods in wild and cultured fish populations. Invertebr Reprod Dev 22:91-102

Tully O, Gargan P, Poole WR, Whelan KF (1999) Spatial and temporal variation in the infestation of sea trout (Salmo trutta L.) by the caligid copepod Lepeophtheirus salmonis (Krøyer) in relation to sources of infection in Ireland. Parasitology 119:41-51

Wadsworth SL (1998) The control of Lepeophtheirus salmonis (Krøyer 1837) (Copepoda: Caligidae) on Atlantic salmon Salmo salar L. production sites. PhD thesis, University of Aberdeen

Wallace C (1998) Possible causes of salmon lice Lepeophtheirus salmonis (Krøyer, 1837) infections on farmed Atlantic salmon, Salmo salar L., in a western Norwegian fjord-situated fish farm: implications for the design of regional management strategies. Thesis Canditatus Scientiarum, University of Bergen

Wootten R, Smith JW, Needham EA (1982) Aspects of the biology of the parasitic copepods Lepeophtheirus salmonis and Caligus elongatus on farmed salmonids, and their treatment. Proc Roy Soc Edin 81b:185-197

Submitted: January 10, 2002; Accepted: August 15, 2003 Proofs received from author(s): November 7, 2003 